\title{
Genistein Promotes Proliferation of Human Cervical Cancer Cells Through Estrogen Receptor-Mediated PI3K/Akt-NF-KB Pathway
}

\author{
Hai-Hong Chen\#, Shu-Ping Chen\#, Qiu-Ling Zheng, Shao-Ping Nie ${ }^{凶}$, Wen-Juan Li, Xiao-Juan Hu, \\ Ming-Yong Xie ${ }^{\bowtie}$ \\ State Key Laboratory of Food Science and Technology, Nanchang University, Nanchang, Jiangxi, 330047, China. \\ \# These authors contributed equally for this work. \\ $\triangle$ Corresponding authors: Professor Ming-Yong Xie, PhD; Professor Shao-Ping Nie, PhD; Tel/Fax: +86-791-83969009 (M. Y. XIE); Tel/Fax: +86-791-88304452 (S. \\ P. NIE); E-mail address: myxie@ncu.edu.cn; spnie@ncu.edu.cn \\ (c) Ivyspring International Publisher. This is an open access article distributed under the terms of the Creative Commons Attribution (CC BY-NC) license \\ (https://creativecommons.org/licenses/by-nc/4.0/). See http://ivyspring.com/terms for full terms and conditions.
}

Received: 2017.04.10; Accepted: 2017.06.25; Published: 2018.01.01

\begin{abstract}
Phytoestrogens are polyphenol compounds which have similar structure to $17 \beta$-estradiol (E2), a kind of main estrogen in women. Thus, phytoestrogens may affect the reproductive and endocrine systems, leading to the development of estrogen-related cancers. The effect of genistein (Gen), one of the most studied phytoestrogens, on human cervical cancer cells ( $\mathrm{HeLa})$ was investigated in this study. It was found that Gen at concentrations of $0.001,0.01,0.1$ and $1 \mu \mathrm{mol} \mathrm{L}^{-1}$ promoted the proliferation of HeLa cells in a dose-dependent manner. Gen increased the portion of HeLa cells in $\mathrm{S}$ phase and decreased the portion of the cells in Gl phase. Besides, apoptosis rate of the cells was significantly lower when treated with Gen compared with the control group. It was also found that the expression of ERa, Akt or nuclear NF-KB p65 protein was activated by Gen. The correlation between these three proteins may be as following: ERa was the upstream, followed by Akt, and then nuclear NF-KB p65 protein. In addition, the downstream genes of activated nuclear NF-KB p65 were found to be associated with cell cycle and apoptosis of cancer cells. Our results suggested that Gen may stimulate cell proliferation partially through the estrogen receptor-mediated PI3K/Akt-NF-KB pathway and the further activation of the downstream genes of nuclear NF-KB p65.
\end{abstract}

Key words: Gen, Cell cycle, Cell apoptosis, ER, PI3K/Akt, nuclear NF-kB p65

\section{Introduction}

Genistein (Gen), recognized as the predominant isoflavone in soybean enriched foods, is one of the most extensively studied phytoestrogens which are available in Asian diets [1]. Epidemiological studies have provided evidence for a protective role of isoflavones against the development of numerous cancers including breast cancer, cervical cancer and prostate cancer [2]. There were epidemiological data showing that Asian women have a significantly lower risk of breast cancer compared with Western women [3]. Therefore, the supplement of the phytoestrogens like Gen has become prevalent in many countries in order to avoid the potential risk of estrogen-dependent cancers or alleviate the symptoms of menopause [4]. However, the safety and efficacy of Gen intake were questioned, as some studies have shown that the concentration used by the researchers who found the inhibitory effect of Gen on cancers was higher than the level in the plasma [5], and the results about the effect of Gen on cancers were controversial [6]. Therefore, the effect of Gen at lower doses on cancers should be considered.

The Protein Kinase B (Akt) pathway plays a critical role in regulating the balance between cell survival and apoptosis, as well as the proliferation, growth, migration and metabolism [7]. Furthermore, 
the activation of Akt has been reported to be related to the pathogenesis of numerous disorders, including cancers [8]. The main mechanism of Akt's action could be its ability of regulating the downstream node in either promoting or inhibiting ways [9]. For instance, activated Akt can deliver anti-apoptotic signals by phosphorylating the Bad protein whose function was pro-apoptosis under normal circumstances [10]. There was another situation that activated Akt can phosphorylate the p21 Waf1/Cip1 and p27Kip1, two members of the cyclin-dependent kinase inhibitors, resulting in the promotion of the cell cycle. Akt can also affect the cell cycle through cyclin D1, which was significant in G1/S phase transition [11]. Among all the downstream nodes, Nuclear Factor кB p65 (NF-kB p65) was another important signal node that needed to be taken into account. Under non-stimulating conditions, NF-kB p65 was combined with its inhibitor (IKB) in the cytoplasm, showing no function. Once stimulated, the IKB was degraded, and NF-kB p65 translocates to the nucleus and binds to the corresponding DNA-binding sites or interacts with other transcription factors, and then exerts transcriptional regulatory activity and anti-apoptosis function $[12,13]$. In this study, the effect of Gen at lower doses on human cervical cancer and the possible signal transduction pathway involved were investigated.

\section{Materials and methods}

\section{Chemicals}

The human cervical cancer cell line (HeLa) was obtained from American Type culture collection (ATCC). Gen (purity $\geq 99 \%$ ) and estrodiol (purity $\geq 99 \%$ ) were from Sigma (St Louis, MO, USA). Antibodies against ERa, Akt, NF-kB were from Cell Signaling (Beverly, MA, USA). FBS (Fetal bovine serum) and charcoal dextran-treated FBS (CDT-FBS) were from Hyclone (Logan, USA). Dulbecco's modified Eagle medium (DMEM) was obtained from Gibco (Grand Island, NY, USA). 3-[4, 5-dimethylthiazol 2-yl] 2, 5-diphenyltetrazolium bromide (MTT) was purchased from Solarbio (Beijing, China). Cell cycle and apoptosis analysis kits were from KeyGEN (Nanjing, China). Nucleoprotein and cytoplasm protein extraction kit (Nanjing China). Trizol was from Ambion (Texas, USA).

\section{Cell culture and treatment}

The HeLa cells were routinely cultured in DMEM supplemented with $10 \%$ FBS. The cells were maintained at $37^{\circ} \mathrm{C}$ in a humidified incubator with $5 \%$ $\mathrm{CO}_{2}$. Then the medium was changed to phenol red-free DMEM containing 5\% charcoal dextran-treated FBS for 2 days before the experiment.
The cells were treated with $0.001,0.01,0.1$ and 1 $\mu \mathrm{mol} \cdot \mathrm{L}^{-1}$ Gen in the assay of MTT and cycle analysis.

\section{Determination of cell proliferation}

The proliferation of HeLa cells was assessed by MTT assay. HeLa cells were seeded in 96-well plates at the initial density of $10^{4}$ cells per well, and then incubated for $24 \mathrm{~h}$ before the treatment with Gen at different doses. After the treatment for $48 \mathrm{~h}, 20 \mu \mathrm{L}$ MTT solution ( $5 \mathrm{mg} \mathrm{mL}^{-1}$ in PBS) were added into each well, followed by further incubation for $4 \mathrm{~h}$. The supernatant was discarded and $150 \mu \mathrm{L}$ DMSO was added into each well to dissolve the formazan crystals produced. The absorbance was measured at $570 \mathrm{~nm}$ with a microplate reader. Cell proliferation rate was calculated from the value of the absorbance.

\section{Analysis of cell cycle}

HeLa cells were seeded in 6-well plates at the density of $5 \times 10^{5} \mathrm{~mL}^{-1}$. Cells were incubated for $24 \mathrm{~h}$ before the treatment with Gen at different concentrations. After the treatment for $48 \mathrm{~h}$, the cells were harvested by trypsinization, collected and centrifuged at $1000 \mathrm{rpm}$ for $5 \mathrm{~min}$. Then the cells were washed by ice-cold PBS twice, followed by fixing in ice-cold $70 \%$ ethanol at $4{ }^{\circ} \mathrm{C}$ overnight. The ethanol was removed by centrifugation and the cells were washed with cold PBS. The fixed cells were then re-suspended with $100 \mu \mathrm{L}$ RNase $\left(0.6 \mathrm{mg} \mathrm{mL}^{-1}\right)$, incubated in the dark at $37{ }^{\circ} \mathrm{C}$ for $30 \mathrm{~min}$ and then mixed with $400 \mu \mathrm{L}$ propidium iodide (PI, $50 \mu \mathrm{g} \mathrm{mL}-1$ ), followed by the incubation at $37^{\circ} \mathrm{C}$ for $30 \mathrm{~min}$. The cell cycle was then analyzed within one hour by flow cytometry.

\section{Analysis of cell apoptosis}

The cells were seeded in 6-well plates at the density of $5 \times 10^{5} \mathrm{~mL}^{-1}$. The cells were harvested after treating with Gen for $48 \mathrm{~h}$ and washed by PBS twice. Then $500 \mu \mathrm{L}$ Binding Buffer were added to re-suspend the cells. At last, $5 \mu \mathrm{L}$ Annexin V-FITC and $5 \mu \mathrm{L}$ Propidium Iodide were mixed well in the solution, followed by the incubation at room temperature for 10 min in the dark. The cell apoptosis should be assessed within $1 \mathrm{~h}$ by flow cytometry (BD FACSCalibur ${ }^{\mathrm{TM}}$ NewYork USA). WinMDI software was used to analyse the data.

\section{Western blot analysis}

HeLa cells were harvested after $0.1 \mu \mathrm{mol} \cdot \mathrm{L}^{-1} \mathrm{Gen}$ treatment for $0.5 \mathrm{~h}, 1 \mathrm{~h}, 2 \mathrm{~h}$ or $3 \mathrm{~h}$. Cells were lysed, cytoplasmic and nuclear protein factions separated using the Nucleoprotein and Cytoplasm extraction kit, Key GEN BioTECH (Nanjing, China), following the procedure recommended by the manufacturer (or something similar). The protein was electrophoresed 
on $10 \%$ sodium dodecyl sulfate-polyacrylamide gels, and then transferred to nitrocellulose membrane. After bolcking by Bovine Serum Albumin, the membrane was incubated by corresponding antibody (diluted 1:1000) overnight at $4{ }^{\circ} \mathrm{C}$. Then the membrane was washed by TBST solution (containing $0.1 \%$ Tween 20 and 1\% Tris) for 3 times (15 min each time). After washing, the anti-mouse or anti-rabbit IgG (diluted 1:10000) was added to the membranes for $1 \mathrm{~h}$ at the room temperature. The membrane was washed again by the TBST solution for 3 times (15 min each time). The proteins were visualized using enhanced chemiluminescence reagents. The signal was detected using a gel documentation system (Molecular Imager ChemiDoc $^{\mathrm{TM}} \mathrm{XRS}^{+}$Imaging Syste). The intensity of the signal was analyzed by Quantity One and expressed as the relative intensity compared to the control group (taken as $100 \%$ ). $\beta$-actin was used as an internal control.

\section{Reverse transcription -PCR analysis}

Reverse transcription-PCR (ABI Prism 7900HT, Applied Biosystems, USA) was used to detect the expression of Cyclin-D1 and $\mathrm{Bcl} / \mathrm{Bax}$ genes. The reaction time of Gen were $0 \mathrm{~h}, 3 \mathrm{~h}, 6 \mathrm{~h}, 12 \mathrm{~h}$ and 24 $\mathrm{h}$, respectively. Total RNA was extracted from HeLa cells and then reverse transcribed into cDNA. The synthesized cDNA was used for PCR amplification. Primer sequences of selected genes were shown in Table 1. The PCR cycle was as following: initial denaturation at $94{ }^{\circ} \mathrm{C}$ for $3 \mathrm{~min}$, followed by denaturation at $94^{\circ} \mathrm{C}$ for $30 \mathrm{~s}$, annealing at $60^{\circ} \mathrm{C}$ for 30 $\mathrm{s}$ and extension at $72{ }^{\circ} \mathrm{C}$ for $2 \mathrm{~min}$ for 30 cycles, and 10 min at $72{ }^{\circ} \mathrm{C}$ for final extension. The PCR products were separated by electrophoresis on a $2 \%$ agarose gel. $\beta$-actin was used as an internal control.

\section{Statistical analysis}

Data were expressed as means \pm SD from at least three experiments. Statistical analyses for gene and protein expression were performed using the Quantity One Software. Statistical analyses for cell apoptosis were performed using the WinMDI software and the program used to analyze cell cycle phases was ModFit LT V3.2. All statistical analyses were performed using SPSS 13.0 statistical package (One-way Anova Tukey test). A value of $* P<0.05$ was considered to be significantly different. Origin 7.0 was used to draw column diagrams.

\section{Results}

\section{Effect of Gen on cell viability}

Incubation of HeLa cells with Gen at different concentrations $\left(0.001,0.01,0.1\right.$ and $\left.1 \mu \mathrm{mol} \cdot \mathrm{L}^{-1}\right)$ for 48 and $72 \mathrm{~h}$ significantly increased cell proliferation in a dose-dependent manner (Figure 1). The most significant proliferative effect on cell viability in comparison with the control group was achieved at the dose of $0.1 \mu \mathrm{mol} \cdot \mathrm{L}^{-1}$ after $72 \mathrm{~h}$ treatment.

Table 1. Primers used for RT-PCR

\begin{tabular}{|c|c|c|c|c|}
\hline \multicolumn{2}{|c|}{ Primer Sequence } & \multirow{2}{*}{$\begin{array}{l}\begin{array}{l}\text { Size of } \\
\text { product }\end{array} \\
250 \mathrm{bp}\end{array}$} & \multirow{2}{*}{$\begin{array}{l}\operatorname{Tm} \\
\left({ }^{\circ} \mathrm{C}\right) \\
60\end{array}$} & \multirow{2}{*}{$\begin{array}{l}\text { Cycles } \\
30\end{array}$} \\
\hline$\beta$-actin & $\begin{array}{l}\text { Forward:5'-CATGTACGTTGCTATCCAGG } \\
\text { C-3' } \\
\text { Reverse:5'-CTCCTTAATGTCACGCACGAT } \\
-3^{\prime}\end{array}$ & & & \\
\hline $\mathrm{Bcl}-2$ & $\begin{array}{l}\text { 5'-CGACGACTTCTCCCGCCGCTACCGC- } \\
3^{\prime} \\
5^{\prime} \text {-CCGCTAGCTGGGGCCGTACAGTTCC- } \\
3^{\prime}\end{array}$ & $319 \mathrm{bp}$ & 60 & 30 \\
\hline Cyclin-D1 & $\begin{array}{l}\text { 5'-GTGAAGTTCATTTCCAATCCGC-3' } \\
\text { 5'-GGGACATCACCCTCACTTAC-3' }\end{array}$ & $167 \mathrm{bp}$ & 60 & 30 \\
\hline VEGF & $\begin{array}{l}\text { 5'-ATGGCAGAAGGAGGAGGG-3' } \\
\text { 5'-CGAAACGCTGAGGGAGGCT-3' }\end{array}$ & $420 \mathrm{bp}$ & 60 & 30 \\
\hline u-PA & $\begin{array}{l}\text { 5'-TCACCACCAAAATGCTGTGT-3' } \\
\text { 5'-AGGCCATTCTCTTCCTTGGT-3' }\end{array}$ & $231 \mathrm{bp}$ & 60 & 30 \\
\hline TRAF & $\begin{array}{l}\text { 5'-AGAGGCCCCAGAGTGAAACC-3' } \\
\text { 5'-AGATGGCCAGCCCGAAGTCG-3' }\end{array}$ & $294 \mathrm{bp}$ & 60 & 30 \\
\hline c-IAP1 & $\begin{array}{l}\text { 5'-GAAGACATCTCTTCATCGAGG-3' } \\
\text { 5'-CCACAGGTGTATTCATCATGAC-3' }\end{array}$ & $688 \mathrm{bp}$ & 60 & 30 \\
\hline c-IAP2 & $\begin{array}{l}\text { 5'-ACAGGAAGCAAAGCACAGG-3' } \\
\text { 5'-CTGTCCTAGACTTGTTCCGTTA-3' }\end{array}$ & $138 \mathrm{bp}$ & 60 & 30 \\
\hline
\end{tabular}

\section{Effect of Gen on cell cycle}

Flow cytometry assay showed the distribution of cells in different phases of cell cycle. Analysis of cell cycle showed that treatment of cells for $48 \mathrm{~h}$ with Gen increased the percentage of cells in $S$ phase and decreased the percentage of cells in G1 phase, and the number of cells in $S$ phase was the highest at the concentration of $0.010 \mu \mathrm{mol} \cdot \mathrm{L}^{-1}$ (Table 2).

Table 2. The effect of Gen on cycle of HeLa cells

\begin{tabular}{llllll}
\hline Group & Control & \multicolumn{4}{l}{ Gen $\left(\mu \mathrm{mol} \cdot \mathrm{L}^{-1}\right)$} \\
\cline { 3 - 6 } & & 1.000 & 0.100 & 0.010 & 0.001 \\
\hline G1/\% & $75.59 \pm 4.82$ & $71.87 \pm 7.62$ & $59.48 \pm 6.42^{*}$ & $64.01 \pm 1.90^{*}$ & $67.20 \pm 0.43^{*}$ \\
S/\% & $24.68 \pm 4.38$ & $27.95 \pm 4.43$ & $38.60 \pm 3.32^{*}$ & $38.84 \pm 3.80^{*}$ & $31.62 \pm 1.85^{*}$ \\
\hline
\end{tabular}

Difference was significant when ${ }^{*} p<0.05$ vs Control Group $(\mathrm{n}=3)$

\section{Effect of Gen on cell apoptosis}

It was found that treatment of Gen at all concentrations decreased the apoptosis rate of HeLa cells significantly as compared to the untreated cells (Table 3). The apoptosis rates of treated groups were $(7.82 \% \pm 1.73), \quad(7.05 \% \pm 2.86), \quad(6.72 \% \pm 1.92) \quad$ and $(6.73 \% \pm 1.23)$ at $1,0.1,0.01$ and $0.001 \mu \mathrm{mol} \cdot \mathrm{L}^{-1}$, respectively.

\section{Induced expression of estrogen receptor (ER) $\alpha$, PI3K/Akt and nuclear NF-KB p65 by Gen}

To determine whether PI3K/Akt and nuclear NF-KB p65 signal transduction pathways were related to the proliferative effect of Gen on HeLa cells, 
expression levels of ERa, p-Akt and nuclear NF-KB p65 proteins were detected by western blotting. Gen at $0.1 \mu \mathrm{mol} \cdot \mathrm{L}^{-1}$, the concentration which had the most significantly proliferative effect in the MTT assay, was used to treat the cells. As shown in Figure 2, the expression levels of ERa, p-Akt and nuclear NF-KB p65 of the Gen-treated group were much higher than the control group.

Table 3. The effect of Gen on apoptosis of HeLa cells

\begin{tabular}{|c|c|c|c|c|c|}
\hline \multirow[t]{2}{*}{ Group } & \multirow[t]{2}{*}{ Control } & \multicolumn{4}{|c|}{ Gen $\left(\mu \mathrm{mol} \cdot \mathrm{L}^{-1}\right)$} \\
\hline & & 1.000 & 0.100 & 0.010 & 0.001 \\
\hline Apoptosis/\% & $11.34 \pm 1.60$ & $7.82 \pm 1.73^{*}$ & $7.05 \pm 2.86^{*}$ & $6.72 \pm 1.92^{* *}$ & $6.73 \pm 1.23^{* *}$ \\
\hline
\end{tabular}

Besides, we also determined the cell viability when the cells were incubated with Gen and an inhibitor of ERa (MPP), p-Akt (LY294002) or nuclear NF-kB p65 (PDTC) to further determine whether Gen-induced proliferative effect was associated with the activation of these proteins. As shown in Figure 3, cell viabilities of the groups treated with both Gen and each inhibitor were significantly lower than the group treated with Gen alone. These results further confirm the relationship between the increased cell viability and activation of ERa, PI3K/Akt or nuclear NF-KB p65 protein.

\section{Relationship between ER $\alpha$ and PI3K/Akt INF-KB p65 pathway}

MPP and LY294002 are the specific inhibitors of ERa and PI3K/Akt respectively. To determine the connection between ERa and PI3K/Akt/NF-kB p65 pathway, the blocking ability of MPP and LY294002

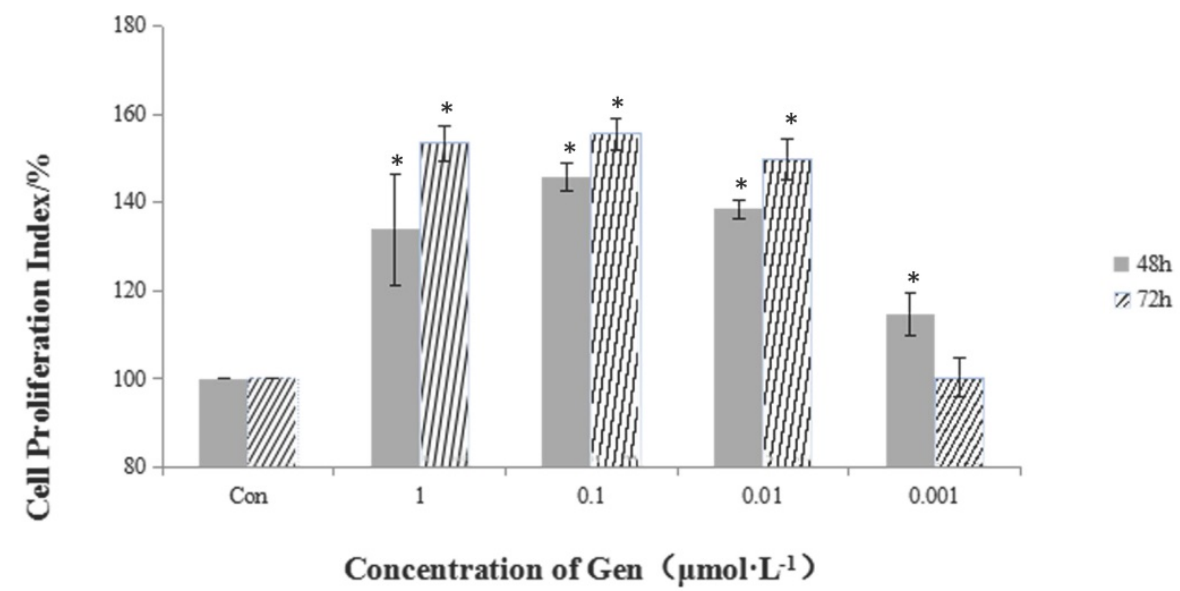

Figure 1. The proliferative effect of different concentrations of Gen on HeLa cells. Gen groups were treated with increasing doses $(0.001,0.01,0.1$ and $1 \mu \mathrm{mol} \cdot \mathrm{L}-1)$ for $48 \mathrm{~h}$ and $72 \mathrm{~h}$. Cell proliferation index was obtained by the formula: PR\% = (OD value of the Gen group/OD value of the control group $) \times 100 \%$. Difference was significant when $* p<0.05$ vs Control Group $(\mathrm{n}=3)$. was investigated. As shown in Figure 4, expression level of p-Akt was lower when the cells were treated with MPP. Furthermore, expression level of nuclear NF-kB p65 was also lower after treating with LY294002. These results indicated that ERa was activated before PI3K/Akt, followed by the activation of NF-kB p65.

\section{Gen modulates the expression of the downstream genes of NF-KB}

Gen was found to activate nuclear NF-kB which has the ability of regulating the expression of several cell cycle and apoptosis related genes. Therefore, we determined (urokinase type plasminogen activator), TRAF (tumour-necrosis factor receptor associated factor)-1, and c-IAP-1/2 (two inhibitors of apoptosis family). As shown in Figure 5, gene expression level of Cyclin D1 increased, which could explain the shortening of G1 phase in the cells. The increased gene expression levels of Bcl-2, VEGF, u-PA and TRAF-1, and the decreased gene expression level of c-IAP-1 could explain the reduction of apoptosis rate of the cells. In addition, the stable expression of c-IAP-2 suggested that c-IAP-2 may not be associated with apoptosis of the cells.

\section{Discussion}

Cervical cancer is one of the leading causes of death in women around the world. Previous studies have found the therapeutic effect of phytoestrogen on cervical cancer. However, the concentrations (above 1 $\mu \mathrm{mol} \cdot \mathrm{L}^{-1}$ ) used in the therapy were much higher than the plasma level in healthy people and its content in the diets [14, 15, 16]. It has been reported that phytoestrogen can not only exert the anti-estrogenic effect (at high concentrations), but also the estrogenic effect (at low concentrations) [17]. Therefore, taking the average dietary intake of Gen into account, the study on the effect of Gen at lower concentrations was of more practical significance. In the present study, we thus investigated the estrogenic effect of Gen at 0.001 $\mu \mathrm{mol} \mathrm{L}^{-1}$ to $1 \mu \mathrm{mol} \mathrm{L}^{-1}$ on human cervical cancer in vitro, and the possible molecular mechanism of its action. 
A $\begin{array}{lllll}0 \mathrm{~h} & 0.5 \mathrm{~h} & 1 \mathrm{~h} & 2 \mathrm{~h} & 3 \mathrm{~h}\end{array}$
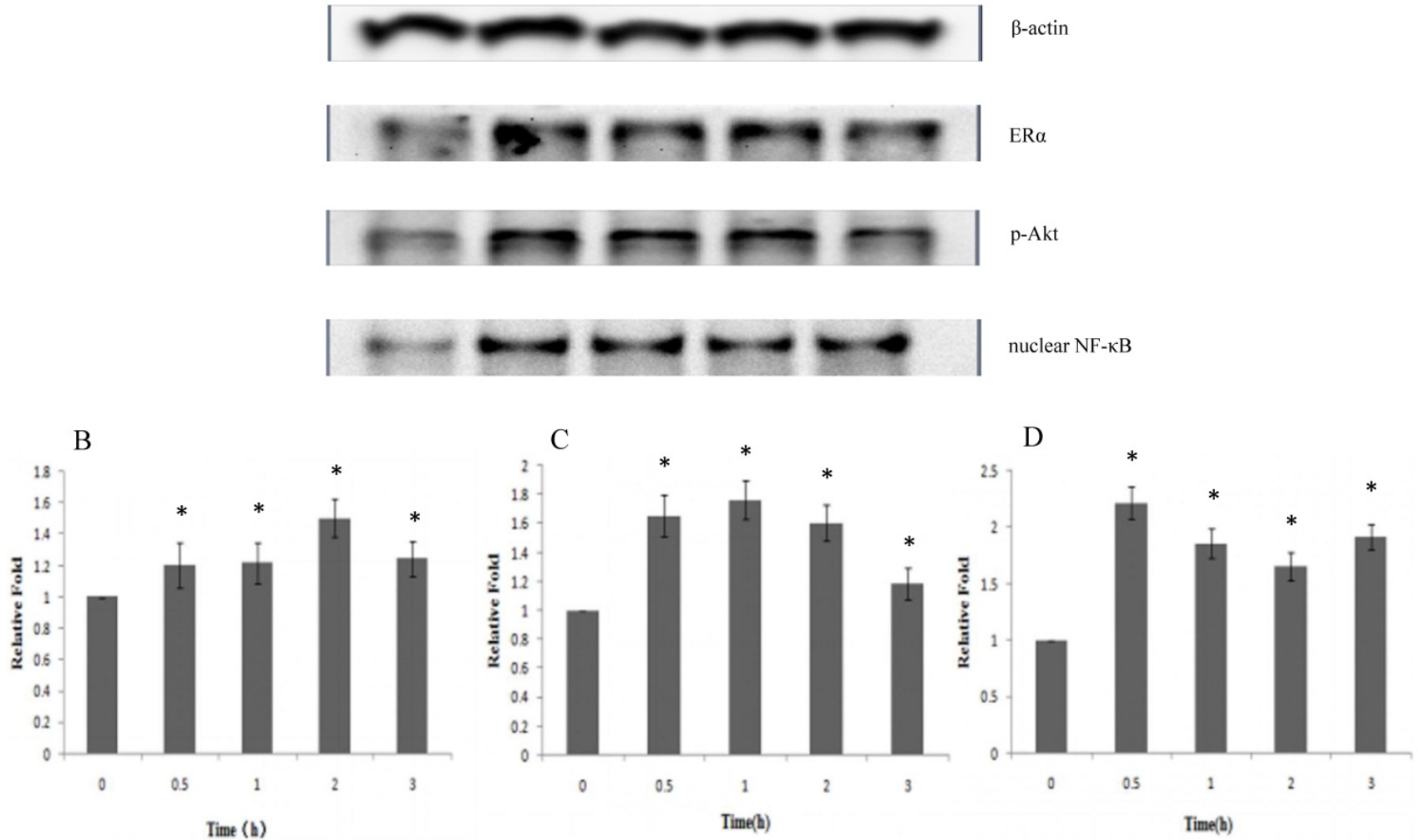

Figure 2. A : The expression of ER $\$ `p-Akt and nuclear NF-KB p65 proteins of HeLa cells treated with Gen; B: The effect of Gen on the expression of ER $\alpha$ protein. ${ }_{p}^{*}<0.05$ vs control group $(t=0), n=3$. C: The effect of Gen on the expression of $p$-Akt protein. ${ }^{p}<0.05$ vs control group $(t=0)$, $n=3$. $D$ : The effect of Gen on the expression of nuclear NF-KB p 65 protein. ${ }^{*}<0.05$ vs control group $(t=0)$, $n=3$. Gen induced activation of ER $\alpha$, PI3K/Akt and nuclear NF-KB p65 proteins in HeLa cells. HeLa cells were treated with Gen $(0.1 \mu \mathrm{mol} \cdot \mathrm{L}-1)$ for increasing time points $(0,0.5,1,2$ and $3 \mathrm{~h})$. Time course study of protein expression of ER $\alpha$ - $p$-Akt and nuclear NF-KB p 65 by Western blotting.

Previously studies shown that Gen could inhibit cell proliferation and induce apoptosis: Yang et al. reported that Gen $\left(25,50,100 \mu \mathrm{mol} \cdot \mathrm{L}^{-1}\right)$ suppressed the viability of HeLa cells, caused apoptosis in a dose dependent manner and ER stress contributes to Gen-induced apoptosis in cervical cancer cells [18]. Ouyang et al. reported that exposure of human ovarian cancer HO-8910 cells to Gen $\left(100 \mu \mathrm{mol} \cdot \mathrm{L}^{-1}\right)$ could induce DNA damage, triggers $\mathrm{G} 2 / \mathrm{M}$ phase arrest and cell apoptosis [19]. While according to our study the effect of Gen on HeLa cells were totally different when treated HeLa cells with low concentrations of Gen (0.001-1 $\left.\mu \mathrm{mol} \cdot \mathrm{L}^{-1}\right)$. We determined whether Gen could exert proliferative effect on HeLa cells by examining cell viability, cell cycle distribution by MTT assay and flow cytometry respectively. The results showed that Gen promoted cell proliferation and enhanced the portion of cells in $S$ phase. We then investigated whether Gen might also affect the apoptosis of HeLa cells as apoptosis plays an important role in maintaining cell homeostasis. These results suggested that Gen may influence cell proliferation through its ability of regulating cell cycle and apoptosis.

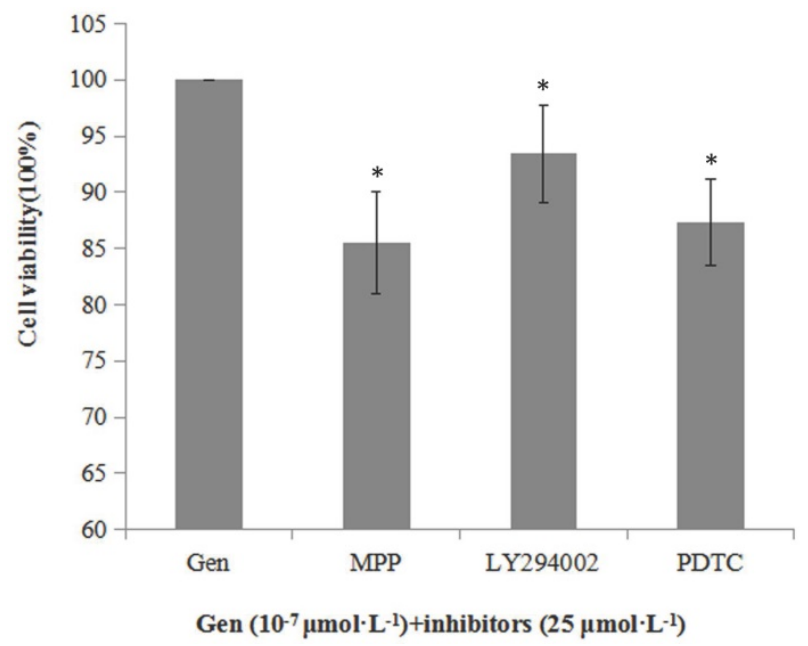

Figure 3. Inhibitory effect of MPP, LY294002 and PDTC (25 $\mu \mathrm{mol}$ L-1) on viability of HeLa cells treated with Gen at $0.1 \mu \mathrm{mol} \cdot \mathrm{L}-1$, $(\mathbf{n = 3})$. Cells were incubated with Gen and each inhibitor for $24 \mathrm{~h}$. Difference was significant when ${ }^{*} p<0.05$ vs Control Group (inhibitor $=0$, defined as $100 \%)$. 


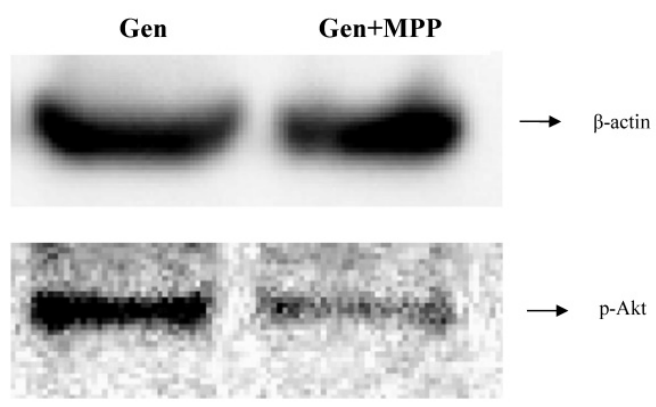

B

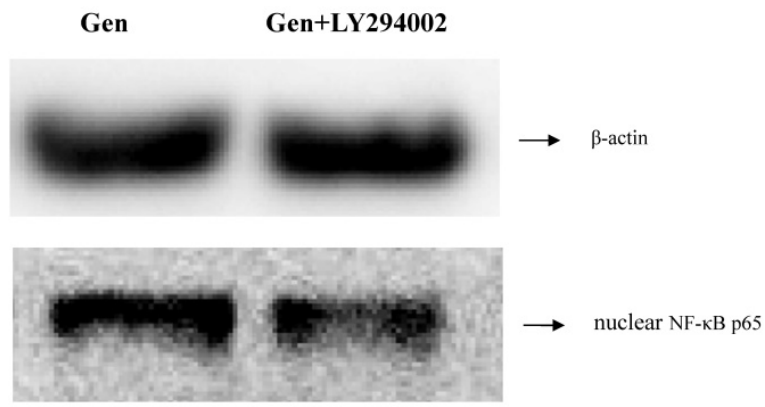

Figure 4. The correlation determination between the ER $\alpha, p-A k t$ and nuclear NF-KB p65. A: Cells of three groups were incubated for $1 \mathrm{~h}$. Then the expression levels of $\mathrm{p}$-Akt protein was analyzed by western blotting. $\mathrm{B}$ : Cells of three groups were incubated for $1 \mathrm{~h}$. Then the expression of nuclear NF-KB 055 protein was detected by western blotting.

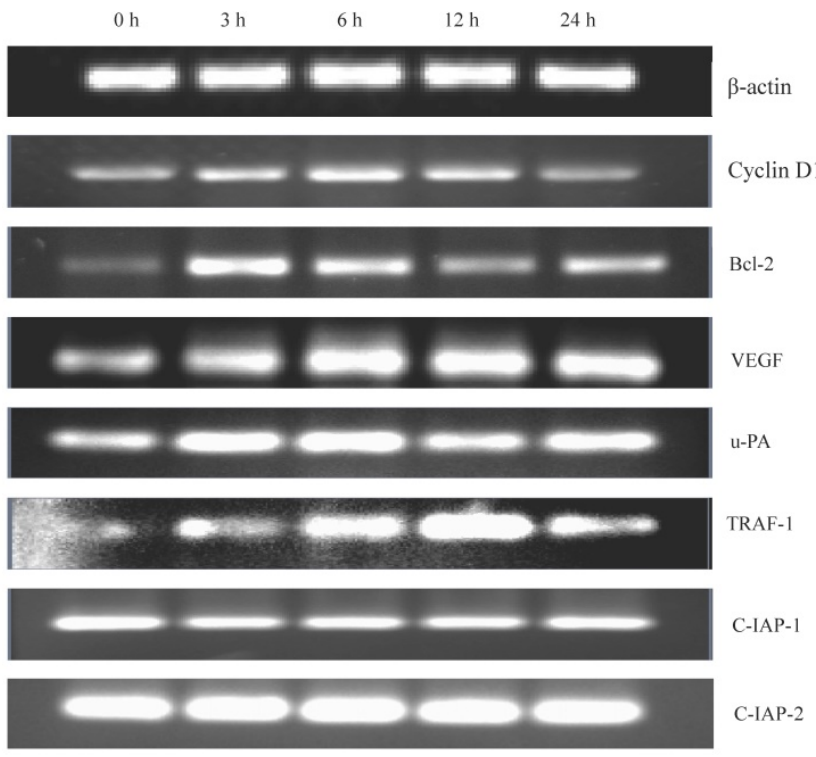

Figure 5. The detection of the related downstream genes of NF-KB. Some downstream genes of NF-KB, Cyclin DI, Bcl-2, VEGF, u-PA, TRAF-1, C-IPA-1 and c-IPA-2 were detected. The cells were treated with Gen for increasing time points $(0,3,6,12$ and $24 \mathrm{~h})$. The gene expression was analysed by RT-PCR

E2 could bind to ER and trigger ER-mediated responses [20]. Gen had similar chemical structure to E2, thus allowing it competitively bind to ER [21]. To determine whether Gen could activate the estrogenic pathway, we analyzed the expression of ERa in HeLa cells. It was found that expression of ERa protein significantly increased as compared with the control group. Besides, we used MPP (an inhibitor of ER) to block the ER pathway, and found that the proliferative effect of Gen has been weakened to a certain extent, but not entirely. This result indicated that Gen may exert its proliferative effect partially through ER-mediated pathway, and there might be other pathways involved here.

The development of cancers is a complex process which involves various factors and pathways. Within these factors, there are many connections and crosstalks between them. For instance, the upstream proteins can activate downstream proteins by phosphorylation and activated protein might have the ability of regulating some related genes which can regulate other proteins in turn [22]. Eventually, it would generate a series of comprehensive responses. In this study, we mainly focused on the PI3K/Akt pathway because of its important role in controlling the balance between cell survival and apoptosis, especially in cancer progression. The results showed that expression levels of p-Akt protein in Gen-treated groups were much higher as compared with the control group. These results suggested that PI3K/Akt pathway was indeed activated by Gen. In addition, the cell viability was weakened by LY294002, which has the ability of inhibiting Akt activity specifically. It was concluded from these results that PI3K/Akt pathway might be associated with the proliferative effect induced by Gen. Then, among all the downstream proteins of Akt, we further determined the expression of nuclear NF-kB p65 because it was an important nuclear transcription factor that could regulate cycle and apoptosis-related genes and also has been reported to be involved in estrogen response pathway [23]. It was found that nuclear NF-кB p65 protein expression level was significantly increased by Gen. Furthermore, blocking of nuclear NF-кB p65 by its inhibitor PDTC was found to weaken the cell viability, suggesting the correlation between the nuclear NF-kB p65 and the proliferative effect of Gen.

$\mathrm{NF}-\mathrm{kB}$ has been reported to influence the development and metastasis of tumor because of its ability of regulating many related genes [24]. In order to explore the role of Gen on cell cycle and apoptosis, we selected several downstream genes of NF-kB which were related to the regulation of cell cycle or apoptosis. Cyclin D1, a regulator of cell cycle, exerts its role with cyclin-dependent kinases and their inhibitors, whose contents change with the cell cycle. The overexpression of Cyclin D1 was characteristic of a variety of human tumors. Some studies have 
suggested that its overexpression could shorten the G1 phase, leading to cell proliferation [25-28]. Bcl-2 was one of the members in Bcl-2 family which were associated with apoptosis. When Bcl-2 was relatively excessive, cells can avoid apoptosis [29]. VEGF was a cytokine secreted by malignancies. It has the strongest effect on promoting angiogenesis among all the pro-angiogenic regulatory factors, which can promote tumor angiogenesis, thus contributing to tumor growth and progression [30]. Activated u-PA can promote the degradation of extracellular matrix, and then the tumor invasion and metastasis can be achieved [31, 32]. TRAF-1 and c-IAP1/2 were two main factors that were associated with the apoptosis like the Bcl-2 family [33]. The RT-PCR results showed that these genes were indeed up-regulated or down-regulated. And the variation of these genes was in accordance with the change of cell cycle and apoptosis rate of HeLa cells, which could further explain the proliferation of HeLa cells.

\section{Conclusions}

Gen triggered the activation of ER, PI3K/Akt and NF-KB pathways one after another, and then regulated the expression of related genes through activation of NF-kB, resulting in the variation of cell cycle and apoptosis and leading to the proliferative effect eventually. The results reflected the effect of these proteins on the proliferation of HeLa cells. However, there might be other pathways through which Gen exerted its function because blocking of this pathway did not suppress the promoting effect entirely. Overall, the study has demonstrated the proliferative effect of Gen on HeLa cells, the important role of ER, PI3K/Akt or NF-KB in this effect, and the possible reasons of causing this effect. The results may provide some experimental and theoretical basis for the necessity of being cautious about the intake of phytoestrogen and the use of phytoestrogen in cancer therapy.

\section{Abbreviations}

Gen, genistein; Akt, Protein Kinase B; E2, $17 \beta$-estradiol; $E R \alpha$, estrogen receptor $\alpha$; $\mathrm{I}-\mathrm{kB}$, inhibitors of $\kappa B$; NF-кB, Nuclear Factor $\kappa B$; TRAF-1, tumour-necrosis factor receptor associated factor-1; u-PA, urokinase type plasminogen activator; VEGF, vascular endothelial growth factor.

\section{Acknowledgement}

The financial support for this study by Joint Sino-German Research Project of National Natural Science Foundation of China (No.GZ 731), International Science \& Technology Cooperation Program of China (No.2010DFA31780), National
Natural Science Foundation of China Used to Support regional science fund (NO.81460468), Jiangxi Youth Science Foundation Program (NO. 20142BAB215044),is gratefully acknowledged.

\section{Authors and Contributors}

S.P. N., M.Y. X., W.J. L. designed research; H.H. C., S.P. C., Q.L. Z. performed research and analyzed data, H.H. C., S.P. C.,X.J. H. wrote the paper.

\section{Competing Interests}

The authors have declared that no competing interest exists.

\section{References}

[1] Rahman S, Islam R, Swaraz AM. An insight on genistein as potential pharmacological and therapeutic agent. Asian Pac J Trop Biomed. 2012; 2: 1924-1937.

[2] Duncan AM, Phipps WR, Kurzer MS. Phyto-oestrogens. Best Pract Res Cl En. 2003; 17: 253-271.

[3] Wu Q, Yang Y, Yu J. Soy isoflavone extracts stimulate the growth of nude mouse xenografts bearing extrogen-dependent human breast cancer cells (MCF-7). J Biomed Res. 2012; 26: 44-52.

[4] Jawaid K, Crane SR, Nowers JL. Long-term genistein treatment of MCF-7 cells decreases acetylated histone 3 expression and alters growth responses to mitogens and histone deacetylase inhibitors. J Steroid Biochem Mol Biol. 2010; 120: 164-171.

[5] Liu HQ, Du J, Hu CY. Delayed activation of extracellular-signal-regulated kinase $1 / 2$ is involved in genistein- and equol-induced cell proliferation and estrogen-receptor-a-mediated transcription in MCF-7 breast cancer cells. J Nutr Biochem. 2010; 21: 390-396.

[6] Zheng WY, Nie SP, Li WJ. Stimulatory effects of genistein and quercetin on the proliferation of MCF-7 cells. Food Biosci. 2013; 2: 15-23.

[7] Martelli AM, Tabellini G, Bressanin D. The emerging multiple roles of nuclear Akt. Bba-Mol Cell Res. 2012; 1803: 2168-2178.

[8] Cho GW, Shin SM, Namkoong H. The phosphatidylinositol 3-kinase/Akt pathway regulates the HCCR-1 oncogene expression. Gene. 2006; 384: 18-26.

[9] Shtilbans V, Wu MX, Burstein DE. Current overview of the role of Akt in cancer studies via applied immunohistochemistry. Ann Diagn Pathol. 2008; 12: 153-160.

[10] Matsui T, Rosenzweig A. Convergent signal transduction pathways controlling cardiomyocyte survival and function: the role of PI3-kinase and Akt. J Mol Cell Cardiol. 2005; 38: 63-71.

[11] Martelli AM, Evangelisti C, Chiarini F. The emerging role of the phosphatidylinositol 3-kinase/Akt/mammalian target of rapamycin signaling network in normal myelopoiesis and leukemogenesis. Bba-Mol Cell Res. 2010; 1803: 991-1002.

[12] Chakraborti S, Chakraborti T. Oxidant-mediated activation of mitogen activated protein kinases and nuclear transcription factors in the cardiovascular system: A Brief Overview. Cell Signal. 1998; 10: 675-683.

[13] Kingeter LM, Schaefer BC. Malt1 and cIAP2-Malt1 as effectors of NF-kB activation: Kissing cousins or distant relatives. Cell Signal. 2010; 22: 9-22.

[14] Jakubowicz-Gil J, Paduch R, Piersiak T. The effect of quercetin on pro-apoptotic activity of cisplatin in HeLa cells. Biochem Pharmacol. 2005; 69: 343-1350.

[15] Priyadarsini RV, Murugan RS, Maitreyi S. The flavonoid quercetin induces cell cycle arrest and mitochondria-mediated apoptosis in human cervical cancer (HeLa) cells through p53 induction and NF-кB inhibition. Eur J Pharmacol. 2010; 649: 84-91.

[16] Hussain A, Harish G, Prabhu SA. Inhibitory effect of genistein on the invasive potential of human cervical cancer cells via modulation of matrix metalloproteinase- 9 and tissue inhibitors of matrix metalloproteinase- 1 expression. Cancer Epidemiol. 2012; 36: 387-393.

[17] Duursen MV, Nijmeijer SM, Morree ED. Genistein induces breast cancer-associated aromatase and stimulates estrogen-dependent tumor cell growth in vitro breast cancer model. Toxicology. 2011; 298: 67-73.

[18] Yang YM, Yang Y, Dai WW. Genistein-induced apoptosis is mediated by endoplasmic reticulum stress in cervical cancer cells. Eur Rev Med Pharmacol Sci. 2016; 20: 3292-3296.

[19] Ouyang GL, Yao LM, Ruan K. Genistein induces G2/M cell cycle arrest and apoptosis of human ovarian cancer cells via activation of DNA damage checkpoint pathways. Cell Biol Int. 2009; 33: 1237-1244.

[20] Gao H, Dahlman-Wright K. The gene regulatory networks controlled by estrogens. Mol Cell Endocrinol. 2011; 334: 83-90.

[21] Lin CC, Tsai YL, Ho CT. Determination of the differential estrogenicity of isoflavonoids by E2-ER-ERE-dependent gene expression in recombinant yeast and MCF-7 human breast cancer cells. Food Chem. 2008; 108: 719-726. 
[22] Chen GG, Zeng Q, Tse GMK. Estrogen and its receptors in cancer. Med Res Rev. 2008; 28: 956-974.

[23] Lee YK, Park OJ. Soybean isoflavone genistein regulates apoptosis through NF-B dependent and independent pathways. Exp Toxicol Pathol. 2013; 65: 1-6.

[24] Lu H, Shi JX, Zhang DM. Inhibition of hemolysate-induced iNOS and COX-2 expression by genistein through suppression of NF-KB activation in primary astrocytes. J Neurol Sci. 2009; 278: 91-95.

[25] Lee CCR, Fukushima S. Alterations in cyclin D1, p53, and the cell cycle related elements: Implications for distinct genetic pathways of urinary bladder carcinogenesis. Urol Oncol. 1998; 4: 58-72.

[26] Arber N, Gammon MD, Hibshoosh H. Overexpression of Cyclin D1 occurs in both squamous carcinomas and adenocarcinomas of the esophagus and in adenocarcinomas of the stomach. Hum Pathol. 1999; 30: 1087-1092.

[27] Roy PG, Thompson AM. Cyclin D1 and breast cancer. Breast. 2006; 15: 718-727.

[28] Park KI, Park HS, Kang SR. Korean Scutellaria baicalensis water extract inhibits cell cycle G1/S transition by suppressing cyclin D1 expression and matrix-metalloproteinase-2 activity in human lung cancer cells. J Ethnopharmacol. 2011; 133: 634-641.

[29] Bonneau B, Prudent J, Popgeorgiev N. Non-apoptotic roles of Bcl-2 family: The calcium connection. Bba-Mol Cell Res. 2013; 1833: 1755-1765.

[30] Guo YP, Wang SH, Hoot DR. Suppression of VEGF-mediated autocrine and paracrine interactions between prostate cancer cells and vascular endothelial cells by soy isoflavones. J Nutr Biochem. 2007; 18: 408-417.

[31] Ferrer R, Marugan I, liuch A. Prognostic relevance of plasminogen activator u-PA in human breast cancer. Eur J Cancer. 1993; 29: S63.

[32] Chen PN, Kuo WH, Chiang CL. Black rice anthocyanins inhibit cancer cells invasion via repressions of MMPs and u-PA expression. Chem-Biol Interact. 2006; 163: 218-229.

[33] Shishodia SB, Aggarwal B. Nuclear factor-kB: a friend or a foe in cancer. Biochem Pharmacol. 2004; 68: 1071-1080. 